\title{
Ruh Sağlığı Çalışanı Adaylarının Toplumsal Cinsiyet Rolleri ve Çelişik Duygulu Cinsiyetçiliğe İlişkin Tutumları*
}

Melike Koçyiğit $^{* * 1}$ ve Gülgün Meşe $e^{2}$

Öz

Anahtar Sözcükler

$\mathrm{Bu}$ araştırma, lisans düzeyinde öğrenim görmekte olan psikolojik danıșman ve psikolog adaylarının toplumsal cinsiyet rolleri ve cinsiyetçiliğe ilişkin tutumlarını ortaya koymayı ve bu tutumların meslekî hizmetlerini nasıl etkileyeceğine ilişkin görüşlerini belirlemeyi amaçlamaktadır. $\mathrm{Bu}$ karma desen araştırmasında veriler, 465 lisans öğrencisinden, Toplumsal Cinsiyet Rolleri Tutum Ölçeği ve Çelişik Duygulu Cinsiyetçilik ölçeği aracılığıyla toplanmıştır. Nitel veriler yarı yapılandırılmış görüşme ile elde edilmiştir. Verilerin analizinde $t$ testi ve içerik analizi kullanılmıștır. Sonuçlar, kadın ve erkek öğrencilerin, toplumsal cinsiyet rolleri ve çelişik duygulu cinsiyetçiliğe ilişkin tutumları arasındaki farklılığın anlamlı olduğunu ortaya koymuştur. Psikoloji bölümü öğrencilerinin düşmanca cinsiyetçilik ve korumacı cinsiyetçilik puanlarının daha düşük olduğu sonucuna ulaşılmıştır. Nitel veriler ise danışan/ruh sağlı̆̆ çalışanının cinsiyet tercihi, ruh sağlığ çalışanına ilişkin varsayımlar, danışana ilişkin varsayımlar, ruh sağlığ çalışanının müdahaleleri, ruh sağlı̆̆ı çalışanının ihtiyaçları şeklinde temalandırılmıştır. Araştırmanın bulgularında, öğrencilerin cinsiyetçi tutumlarının azaltılmasına, eşitlikçi bir anlayıș benimsemelerinin desteklenmesine, toplumsal cinsiyet eşitliği konusunda farkındalıklarını ve

Cinsiyetçilik

Toplumsal cinsiyet

Psikolog

Psikolojik danışman

Makale Hakkında

Gönderim Tarihi

07 Ekim 2019

Kabul Tarihi

22 Nisan 2020

Makale Türü

buna uygun becerilerini geliştirmelerine ihtiyaç duydukları görülmektedir.

Araştırma Makalesi

DOI: $10.12984 /$ egeefd.630339

\section{Gender Roles and Ambivalent Sexism Attitudes of Mental Health Professional Candidates"}

Abstract

Keywords

This study aimed to determine the gender roles and sexism attitudes of counselor and psychologist candidates at the undergraduate level and to determine their views on how these gender roles and attitudes will affect their professional services. For this purpose, in this mixed study research, data were collected from 465 undergraduate students by using the Gender Role Attitude Scale and the Ambivalent Sexism Scale. Qualitative data were obtained by a semi-structured interview. In the analysis of quantitative data, $t$ test was used and the qualitative data were analyzed by content analysis. The results showed that there was a significant difference between the mean score of Gender Role Attitude and ambivalent sexism of female and male students. Another finding revealed that the hostile and benevolent sexism scores of the students of the psychology department were lower. The qualitative data were thematized as gender preference of clients and mental health professionals, assumptions regarding mental health professionals, assumptions related to the client, mental health professionals' interventions, mental health professionals' needs. The findings of the study show that students need to reduce their sexist attitudes, develop their awareness of gender equality, and develop skills accordingly.

Sexism

Gender

Psychologist

Counselor

Article Info

Received

October 07, 2019

Accepted

April 22, 2020

Article Type

Research Paper

Attf: Koçyiğit, M. ve Meşe, G. (2020). Ruh sağlığı çalışanı adaylarının toplumsal cinsiyet rolleri ve çelişik duygulu cinsiyetçiliğe iliş̧kin tutumları. Ege Eğitim Dergisi, 21(1), 01-18. doi:10.12984/egeefd.630339

\footnotetext{
* Bu çalışma sorumlu yazarın yüksek lisans tezinden hazırlanmış olup bir kısmı 2-4 Mayıs 2019'da İzmir'de düzenlenen I. Uluslararası Bilim, Eğitim, Sanat ve Teknoloji Sempozyumu'nda sözlü bildiri olarak sunulmuştur. [This study was prepared from the master thesis of the corresponding author and a part of it was orally presented in the 1st International Science, Education, Art \& Technology Symposium held on 2-4 May 2019 in İzmir, Turkey]

** Sorumlu Yazar/Corresponding Author

1 (D) Akdeniz Üniversitesi, Eğitim Fakültesi, Eğitim Bilimleri Bölümü, Rehberlik ve Psikolojik Danışmanlık Anabilim Dalı, Türkiye, mkocyigit@akdeniz.edu.tr

2 Ege Üniversitesi, Edebiyat Fakültesi, Psikoloji Bölümü, Türkiye, gulgun.mese@ege.edu.tr
} 


\section{Extended Abstract}

\section{Introduction}

Gender roles are one of the factors that are constructed through the process of acculturation and affect the individual's life. This research focuses on the effects of gender roles on the psychological help process for both clients and mental health professionals. At this point, the level of awareness, knowledge, and skills of mental health professionals comes into prominence. When undergraduate programs of psychology and guidance and counseling were examined, it was seen that a limited number of universities have an elective course on gender in the curriculum. On the other hand, both undergraduate programs deal with gender and gender roles in the context of many subjects and courses such as psychology theories, feminist therapy, and social psychology. However, the objectives and learning outcomes of these courses are not directly related to gender. Therefore, it is difficult to say that all of the candidates for psychologists and counselors gain knowledge and skills about gender equality before graduation. However, it is foreseen that mental health professionals will need knowledge and awareness about gender roles that their clients adopt, maintain, or seek to change.

This research aimed to examine the gender role attitudes and sexism levels of the counselor and psychologist candidates and to determine their views on how these roles will affect their professional services. Thus, it is thought that before graduation, it is possible to conduct training and intervention plans for the counselor and psychologist candidates to adopt an egalitarian understanding of gender roles, to raise their awareness on gender equality and to develop appropriate skills. The research questions are as follows:

1. Do counselor and psychologist candidates' attitudes towards gender roles, hostile and benevolent sexism scores differ according to sex?

2. Do counselor and psychologist candidates' attitudes towards gender roles, hostile and benevolent sexism scores differ according to the department?

3. What are the counselor and psychologist candidates' opinions about the effect of attitudes towards gender roles on their professional work?

The hypotheses related to the research questions are presented below:

1. Female students' attitudes towards gender roles are more egalitarian than male students, and their hostile and benevolent sexism scores are lower.

2. Counselor and psychologist candidates' attitudes towards gender roles, hostile and benevolent sexism scores differ according to the department.

\section{Method}

This research was a mixed-method study. The sample, in which the quantitative data were collected, consisted of students of the guidance and counseling and psychology department of a public university. Of the total 465 students, 123 were female and 327 were male. In the collection of qualitative data, 12 students (six females, six males) who volunteered and shared their contact information among the highest and lowest gender roles attitude scores, hostile and protective sexism scores were identified. Demographic information form, Gender Role Attitude Scale, Ambivalent Sexism Scale and, a semi-structured interview form were used as data collection tools. Quantitative data were collected from the students studying in related departments during class hours. The data collection process lasted about 10-15 minutes and was carried out by the researcher. Qualitative data were collected through face-to-face interviews with volunteer students following the quantitative data analysis.

\section{Findings}

There was a significant difference between male and female students' attitudes towards gender roles. The mean attitude score of female students towards gender roles is higher than male students. In addition, there was a significant difference between the mean scores of hostile sexism and protectionist sexism of male and female students. It was observed that psychology students had higher attitude scores on gender roles. Also, psychology students' mean scores of the protectionist and hostile sexism were lower.

It was concluded that the mean scores of both protective and hostile sexism of psychology students differed according to their years of study, and this difference stems from the difference between the first and second year. The qualitative findings of the study are themed as gender preference of clients and mental health professionals, assumptions about mental health professionals, assumptions about the counselor, interventions of mental health professionals, needs of mental health professionals. 


\section{Discussion and Conclusion}

In the literature, it is seen that sex is the determinant of gender perception (Esen, Siyez, \& Soylu, 2017) and the results of the research (Vefikuluçay, Zeyneloğlu, Eroğlu, \&Taşkın 2007) suggesting that men have more traditional attitudes are in parallel with these findings. Also, the results showed that male students had higher hostile sexism scores than female students (Alptekin, 2014; Taşdemir \& Sakall1-Uğurlu, 2010). On the other hand, Taşdemir and Sakall1-Uğurlu (2010) found that there was no difference between the genders in terms of protective sexism scores. Alptekin (2014) found that female students had a higher level of protectionist sexism and those female students were affected by protective sexism. In another study, the sexism level of male counselors was found to be higher than the sexism level of female counselors (Dinçer, 2016).

On the other hand, it is difficult to explain the difference in the departmental curriculum with the undergraduate curriculum. It is necessary to examine the variables such as the place where the students spend most of their lives, the formation of gender roles, the educational status of the parents, and the attitude of the parents in order to reveal the reasons of whether or not the variable of the department brings a differentiation.

The results revealed that in order to become a mental health professional who is sensitive to gender roles, students need to gain knowledge and skills about the effects of gender roles on psychological wellbeing and develop an attitude. Unfortunately, research on mental health professionals and trainees' attitudes toward gender roles, their sexism levels, the impact of gender roles on their services offered is lacking in Turkey. However, effects of mental health workers' attitudes towards gender roles on the services they offer should be discussed, and new studies should be conducted. It is also recommended to conduct long-term experimental and quasiexperimental research in order to develop a more egalitarian attitude. Similar studies with more data from universities in various regions will provide more generalizable results. In addition, obtaining different demographic information from this study may provide more detailed data to explain the differences that may arise. 


\section{Giriş}

Temel amacı, korunaklı, güvenli, gizliliği korunan ve iyileştirici bir ilişki kurarak (Cormier ve Hackney, 2014) bireyin davranışları, duyguları ve düşüncelerinde bir değişim yaratmak (Lambert, Bergin ve Garfield, 2004), iyilik hâlini arttırmak olarak belirtilen psikolojik yardım sürecinin etkili olmasını sağlayan en temel unsurlardan biri, psikolojik yardımı veren ruh sağlığı çalışanının etkili olmasıdır (Hackney ve Cormier, 2008). Meslekî eğitiminin niteliğii; değişime açıklık, kendini kabul edebilme, otantik, samimi olma, yaşamlarını biçimlendirecek tercihler yapabilme özelliklerine sahip olmak gibi (Corey, 2008) pek çok faktörün ruh sağlığı çalışanının etkililiğini belirlediği bilinmektedir. Bu faktörlerden biri de danışanların, içinde bulundukları kültürel bağlamda ele alınmasıdır. Son yıllarda psikolojik yardım sürecini etkilediği öne sürülerek, kültüre duyarlılığın öneminin vurgulandığı dikkat çekmektedir (Heppner, Wampold ve Kivlighan, 2008). Psikolojik yardım sürecinde, danışanın hangi kültürden geldiğini anlamak için; cinsiyet, yaş, yaşadığı yer, büyüdüğü yer gibi demografik değişkenleri; eğitim durumu ve sosyoekonomik düzey gibi statü değişkenleri ve bağlı olduğu grup ya da kurumları irdelemenin gerekliliği öne çıkmaktadır (Launikari ve Puukari, 2005, s. 28, akt. Büyükşahin-Çevik, 2014, s. 582). Bu bakımdan, etkili psikolojik yardım sürecinde, danışanın etkilerini taşıdığı kültür bağlamında ele alınması, her danışanın kendine özgü problemleri ve ihtiyaçları olduğunun düşünülmesi (Umucu ve VoltanAcar, 2011) beklenmektedir. Ruh sağlığı hizmeti sunan profesyonellerin, danışanların kimliğini oluştururken etkilendikleri kültürel faktörlere ilişkin farkındalığa sahip olması gerektiği vurgulanmaktadır.

Kimliğin bir parçasını oluşturan bir faktör olarak cinsiyet ve içinde bulunulan kültürde cinsiyete yüklenen anlam, danışanların yaşadığ 1 problemlerin ele alınmasında, danışanları anlamada önemli bir faktör olarak görülmektedir. Çünkü cinsiyetlere özgü sosyal olarak belirlenen rol ve sorumluluklara karşıllk gelen toplumsal cinsiyet rolleri (Akın ve Demirel, 2003), cinsiyete ilişkin vurguladığı değer yargıları, inançlar ve beklentiler ile bireylerin davranış biçimlerinin belirlenmesinde etkilidir ve bu davranış kalıpları psikolojik yardım sürecine yansımaktadır. Dolayısıyla ruh sağlığı hizmeti sunan profesyonellerin danışanlarının benimsediği, sürdürdüğü ya da değiştirmeye çabaladığı toplumsal cinsiyet rollerine ilişkin bilgi ve farkındalığa ihtiyaç duyacağ düşünülmektedir. $\mathrm{Bu}$ doğrultuda ruh sağlığı hizmeti sunan profesyonellerin, toplumsal cinsiyet rollerinin öğrenilmesini etkileyen faktörleri irdeleyebilmeleri, cinsiyet rollerinin bireyler üzerindeki sınırlayıcı etkisini fark edebilmeleri ve ihtiyaç duydukları değişim konusunda danışana destek olması beklenmektedir. Bu özellikleri, toplumsal cinsiyet rollerine duyarlılık olarak tanımlamak mümkündür.

Toplumsal cinsiyet rolleri ve cinsiyetçiliğin psikolojik yardım sürecine etkileri, danışana ve ruh sağlığı çalışanına ilişkin faktörler olarak ele alınabilir. Öncelikle ruh sağlığ 1 profesyonellerinin bir birey olarak kişisel yaşantılarında toplumsal cinsiyet rollerinin yarattığı etkileri nasıl deneyimlediklerinin farkında olmaları önemlidir. Örneğin bir yardım mesleği seçmenin bile toplumsal cinsiyet rolleri ile ilişkilendirildiği, düşünülmesi gereken bir noktadır. Psikolojik danışmanlık mesleğinde kadınların çoğunlukta olması (Bilge ve Ulukaya, 2011; Brown, 2017; Devoe, 1990; Michel, Hall, Hays ve Runyan, 2013; Quinn ve Chan, 2009), bu tercihlerde kadınların, yardım sunma beklentisinden ve cinsiyet rollerinden ne derece etkilendiği sorusunu akla getirmektedir. Erkek öğrencilerin kendilerinin psikolojik danışma alanında yeri olmadığını hissettiklerini ortaya koyan araştırmalar da (Michel ve diğ., 2013) dikkat çekmektedir. Dolayısıyla ruh sağlı̆̆ı çalışanlarının benimsedikleri cinsiyet rollerinin yaşamlarına, tercihlerine, tutum ve algılarına etkilerini iyi analiz edebilmeleri beklenmektedir. Bu farkındalık, ruh sağlığı çalışanlarının toplumsal cinsiyet rollerine ilişkin duyarlı ve eşitlikçi bir anlayış geliştirmelerinin ilk basamağı olarak düşünülebilir.

Toplumsal cinsiyet rollerinin psikolojik yardım sürecine etkilerini irdelerken öne çıkan diğer özne, danışan ve danışanların toplumsal cinsiyet rolleridir. Danışanla ilgili etkileri, psikolojik yardım arama sürecine yansımaları, danışanları psikolojik yardım almaya iten sorun alanları olarak sınıflandırmak mümkündür. Psikolojik yardım almaya karar verme, uygun yardım kaynakları arama ve psikolojik yardım almaya başlama süreci, toplumsal cinsiyet rollerinin etkisiyle bireylerin psikolojik yardım alma tutumundan ve niyetinden etkilenmektedir. Geleneksel erkek rol beklentileri, erkeklerin psikolojik yardım arama davranışını ve tutumunu olumsuz yönde etkileyebilmekte, erkekler yardım arama sürecinin başlatılmasında zorluk yaşayabilmektedir (McCarthy ve Holliday, 2004). Araştırmalar kadınların erkeklere kıyasla psikolojik yardım almaya yönelik daha olumlu bir tutuma sahip olduğunu (Berger, Levant, McMillan, Kelleher ve Sellers, 2005; Erkan, Özbay, Çankaya ve Terzi, 2012; Kalkan ve Odacı, 2005; Topkaya ve Meydan, 2013) ortaya koymaktadır. Türkiye' de oldukça sınırlı olsa da yurt dışı literatürde 'erkeklerle psikolojik danışma' ayrı bir çalışma alanı olarak görülmektedir. Araştırmalar, cinsiyet rolünün psikolojik yardım aramaya etkisini, erkeklerde cinsiyet rolü karmaşasını ve bu etkilerin psikolojik danışmada ele alınmasını tartışmaktadır (Englar-Carlson, 2006; Evans, 2013). Nitekim psikolojik yardım sürecinde duyguların ifade edilmesi ve erkeğin rollerine ilişkin geleneksel tutumun psikolojik yardım almaya ilişkin olumsuz tutumla ilişkili olduğunu (Good, Dell ve Mintz, 1989; Levant, Wimer, Williams, Smalley ve Noronha, 2009; Nam ve diğ., 2010) ortaya çıkarmıştır. Ayrıca erkeklerin psikolojik problemlerinin, çatışmaya yol açan katı cinsiyet rolleriyle ilişkili olduğu, dolayısıyla ruh sağlığı çalışanının, danışanın, erkeklik ideolojisine 
ne anlam yüklediğini, erkeklik algısının danışanın mevcut problemiyle ilgisini belirlemeye yönelik çalışmasının önemi vurgulanmaktadır (O'Neil, 2013).

Benzer şekilde, cinsiyet rolleri kadınlarda sınırlayıcı yanıyla özelikle depresyon, yeme bozuklukları, uyum problemleri gibi çeşitli ruhsal problemlere yol açmaktadır (Deniz, 1995; McCarthy ve Holliday, 2004; Pederson ve Vogel, 2007; Yücel, 2009). Bilindiği üzere feminist terapi de kadınların deneyimlediği pek çok duygusal, bilişsel ve davranışsal güçlüklerin toplumsal mesajlarla ilişkisini vurgulamaktadır. Örneğin toplumda sıklıkla ve yoğun olarak güzelliğin zayıflıkla ilişkili olduğu mesajı verilmesinin kadınlarda yeme bozukluklarında; cinsiyet rolleri ile ilişkili olarak kadınların deneyimlediği rol karmaşası ve yetersizlik duygularının depresyon ve kaygı bozukluklarında etkili olduğu belirtilmektedir. Özetle, danışanın cinsiyet rolleri ve cinsiyet rolü geçmişi, psikolojik yardım sürecini çok boyutlu olarak etkilemektedir (Scher ve Good, 1990).

$\mathrm{Bu}$ araştırmanın ortaya koymayı hedeflediği, psikolojik yardım sürecine etki edebilecek bir diğer kavram olarak çelişik duygulu cinsiyetçilik, eşitlikçi bir tutum benimsiyor gibi görünerek toplumsal cinsiyet rollerini pekiştiren, yeniden üreten bir tutumun var olmasına işaret etmektedir. Sakallı-Uğurlu'nun (2002) aktardığı üzere, araştırmalar, bireylerin cinsiyetçi tutum ve davranışlara sahip olmanın kötü bir şey olduğunu algıladığını ama bu tür tutum ve davranışlarından vazgeçemedikleri için cinsiyetçi tutum ve davranışlarını açıkça ortaya koymak yerine, daha üstü kapalı bir şekilde ifade ettiklerini ortaya koymaktadır. Çelişik duygulu cinsiyetçilik kavramı düşmanca cinsiyetçilik (hostile sexism) ve korumacı cinsiyetçilikten (ambivalent sexism) oluşmaktadır. "Korumacı cinsiyetçilik, özünde olumlu görülse de kadınların 'zayıf cinsiyet' olduğu fikrini pekiştiren ve bu nedenle erkeklerin korumasına, sevgisine ihtiyaç duyduğuna ilişkin bir inanç setidir” (Glick, Diebold, BaileyWerner ve Zhu, 1997, Akt. Sakalli-Uğurlu ve Glick, 2003, s. 296). Bir başka deyişle korumac1 cinsiyetçilik özünde kadının düşük statüde olduğunu ve erkek egemenliğini savunmaktadır (Sakall1-Uğurlu, 2002). Düşmanca cinsiyetçilik ise kadının zayıf ve ikincil konumunun daha açıkça göründüğü, doğrudan ayrımcı davranışları kapsamaktadır (Glick ve Fiske, 1996). Özetle, korumacı ve düşmanca cinsiyetçilik, erkeklerin gücünün pekiştirilmesinde ve kadınların ikincil konuma itilmesinde birlikte hareket etmektedir (Sakallı-Uğurlu ve Glick, 2003).

Araştırmalarda cinsiyetçiliğin yüksek olduğu toplumlardaki kadınların, düşmanca cinsiyetçiliği ön yargı ve ayrımcılık olarak algılarken, korumacı cinsiyetçiliğe olumlu yaklaştıkları görülmüştür (Sakallı-Uğurlu, 2002). Araştırma sonuçları korumacı ve düşmanca cinsiyetçilikte cinsiyete göre farklılaşma olduğunu, erkeklerin düşmanca cinsiyetçiliğinin daha yüksek olduğunu ortaya koymaktadır (Alptekin, 2014; Ayan, 2014; Taşdemir ve Sakallı, 2010). Dinçer (2016) de erkek okul psikolojik danışmanlarının cinsiyetçilik düzeylerinin daha yüksek olduğu sonucuna ulaşmıştır. Ulaşılan diğer araştırmalar ise düşmanca ve korumacı cinsiyetçiliğin bireylerin cinsel taciz (Ayhan, 2015; Chapleau, Oswald ve Russell, 2007; Sakall1-Uğurlu, Salman ve Turgut, 2010;Salman, 2007; Yalçın, 2006), şiddet (Ercan, 2009; Tarhan, Çetin Gündüz ve Ekşioğlu, 2017), şiddeti meşrulaştırma, (Glick, Sakalli-Uğurlu, Ferreira ve Souza, 2002), evlilik öncesi ilişki deneyimi (Sakallı-Uğurlu ve Glick, 2003) gibi durumlara ilişkin tutumlarıyla ilişkili olduğunu ortaya koymaktadır. Tarhan vd. (2017) ise psikolojik danışman adayları ile yürüttükleri araştırmada, cinsiyetin ve düşmanca cinsiyetçiliğin, sözel şiddete toleransı ve fiziksel şiddet sonrası ayrılmaya yönelik tutumun yordayıcısı olduğu sonucuna ulaşmıştır. Ruh sağlığı çalışanları ile yürütülen bir diğer araştırmada ise düşmanca ve korumacı cinsiyetçilik ile cinsel tacizi kadının kışkırtıcı davranışlarının sonucu ve önemsiz mesele olarak kabul etmeye yönelik tutumlar arasında ilişki bulunmuştur (Ayhan, 2015). Bir diğer bakış açısıyla, danışanların sorun alanlarıyla ilgili olarak ise Oswald, Franzoi ve Frost'un (2012) yürüttüğü araştırmada, babanın korumacı cinsiyetçi tutumlarının, kızlarının kiloya ve fiziksel duruma bağlı beden algılarıyla pozitif yönde ilişkili olduğu bulunmuştur. Öte yandan araştırma sonuçlarında, genç kadınların beden algısının, korumacı cinsiyetçi deneyimleriyle pozitif, düşmanca cinsiyetçi deneyimleriyle negatif yönde ilişkili olduğu görülmüştür. $\mathrm{Bu}$ bulgu da ruh sağlığı çalışanının hem kendisinin cinsiyetçi tutumlardan arınmasının hem de danışanların bu tutumlardan nasıl etkilendiğini fark edebilmesinin gereğini vurgulamaktadır. Özellikle cinsiyet rollerinin bireylere sunduğu ikincil kazançlar, çelişkili cinsiyetçilik tutumlarını belirleyici bir unsur olabilir. Psikolojik yardım süreci bu örüntülerin ortaya çıkabileceği bir ortamdır. Nitekim çelişkili rol beklentileri ve inanışlar da bireylerde rol karmaşası ve duygusal sorunlar yaratabilir. Öte yandan pek çok durum karşısında kadın-erkek eşitliğini savunan, cinsiyetçi tutumu reddeden anlayışa sahip olmanın cinsiyetçiliği ortadan kaldırmak için yeterli olmayacağı düşünülmektedir. Bu noktada, danışanlarla çalışırken ele alınabilecek pek çok sorun alanına ilişkin tutumu da etkilediği göz önüne alındığında, ruh sağlığ çalışanları/adaylarının çelişik duygulu cinsiyetçilik tutumunun nasıl olduğunun belirlenmeye ihtiyacı olduğu görülmektedir.

Toplumsal cinsiyet rollerine ilişkin araştırmaların ise sıklıkla üniversite öğrencileriyle yürütüldüğü dikkat çekmektedir. Bu araştırmalarda, cinsiyet, bölüm, fakülte gibi değişkenler incelenmiştir. Örneğin bir araştırmada, sınıf öğretmeni adaylarının toplumsal cinsiyet rollerine ilişkin tutumlarında cinsiyete göre anlamlı bir farklılık bulunmuştur (Seçgin ve Tural, 2011). Bir diğer araştırmada cinsiyet, sınıf, bölüm ve toplumsal cinsiyet oluşumunun, toplumsal cinsiyet algısını yordadığı görülmüştür (Ünal, Tarhan ve Çürükvelioğlu Köksal, 2017). 
Çok sayıda araştırmada kadın öğrencilerin eşitlikçi tutum düzeylerinin erkek öğrencilere göre daha yüksek olduğu (Pesen, Kara, Kale ve Abbak, 2016; Sis Çelik, Pasinlioğlu, Tan, Koyuncu ve 2013; Vefikuluçay ve diğ., 2007; Yazıcı ve Budak, 2017) sonucu dikkat çekmektedir. Öte yandan diğer araştırma sonuçlarında öğrencilerin üniversitede okudukları sınıf yükseldikçe toplumsal cinsiyet rollerine ilişkin tutumlarının olumlu yönde değiştiği, fen-edebiyat fakültelerinin eşitlikçi tutum puanlarının diğer fakültelerle kıyaslandığında yüksek olduğu cinsiyet, medenî durum, sınıf, fakültenin bu tutumların eşitlikçi ya da geleneksel olmasında yordayıcı olduğu (Başçı ve Giray, 2016) bulguları da görülmektedir. Yine bir diğer araştırmada da fen-edebiyat fakültesi öğrencileri ile eğitim fakültesi öğrencilerinin daha eşitlikçi olduğu ortaya konmuştur (Pesen ve diğg., 2016). Öte yandan eğitim fakültesi öğrencileri için aksini işaret eden araştırmalar da mevcuttur. Eğitim fakültesi öğrencileriyle yürütülen diğer araştırmalarda öğrencilerin eşcinselliğe olumsuz yaklaşımları olduğu (Güney, Karg1 ve Çorbacı Oruç, 2004), farklı kimliklere ilişkin olumsuz tutuma sahip olduğu (Yazıcı ve Budak, 2017) gibi sonuçlar da düşündürücüdür. Türkiye'de eğitim fakültelerinde öğrenim gören üniversite öğrencilerinin toplumsal cinsiyet eşitliğine yönelik görüşlerinin belirlenmesine yönelik bir diğer araştırmada da öğretmen adaylarının, toplumsal cinsiyete ilişkin olumsuz görüşlere sahip olduğu, hatta görüşlerinin eğitim fakültesinde bulundukları süreden olumsuz etkilendiği, bir başka deyişle sınıf düzeyi arttıkça görüşlerinin olumsuza doğru yöneldiği sonucuna da ulaşılmıştır (Acar Erdol, Özen ve Toraman, 2019). Söz konusu araştırmada ingilizce öğretmenliği ile Psikolojik Danışmanlık ve Rehberlik (PDR) bölümlerindeki öğrencilerin diğer bölümlerdeki öğrencilere göre toplumsal cinsiyet konusunda daha eşitlikçi görüşlere sahip oldukları belirlenmiş, bu durum eğitim programında, bireysel farklılıklara saygl, ihmal ve istismardan korunma, şiddeti önleme ve toplumsal cinsiyet eşitliği gibi, toplumsal cinsiyet eşitliğine yönelik doğrudan ya da dolaylı olarak bilgi ve farkındalık kazandırabilecek içerikleri barındırmasıyla açıklanmıştır. Yine bir diğer araştırmada PDR Bölümü öğrencilerinin başta toplumsal cinsiyet olmak üzere farklı kimliklere karşı tutumları diğer bölümlerdeki öğrencilere göre daha olumlu bulunmuş, bu durum, aldıkları eğitimin empati, saygı, koşulsuz kabul gibi tutumlara sahip olmasını desteklediği düşüncesiyle açıklanmıştır (Yazıcı ve Budak, 2017). Öte yandan bu tutumların kazanılması için teorik bilgilerin kazanılmasının yeterli olmadığı da düşünülmektedir.

Toplumsal cinsiyet rollerinin ve cinsiyetçi tutumların hem danışan hem ruh sağlığ 1 çalışanı açısından psikolojik yardım sürecine etkilerinin yadsınamaz olduğu görülmektedir. Cinsiyetçi tutumların ortadan kaldırılması bireyden başlayarak toplumun her kurumunun ve her parçasının sorumluluğudur. Ruh sağlı̆̆ profesyonelleri, değişimin önemli bir parçası olarak görülebilir. Nitekim psikolojik yardım almaya gelen bireyler değişim için bir adım atarak daha sağlıklı davranış örüntüleri geliştirmek için desteklenecekleri bir sürece dahil olmaktadır. Bu noktada ruh sağlığı çalışanlarının bu konuda ne düzeyde farkındalık, bilgi ve beceri sahibi olduğu sorusu öne çıkmaktadır. Bilindiği üzere Türkiye'de ruh sağlığı çalışanları, lisans programları aracılığıyla yetiştirilmektedir. $\mathrm{Bu}$ araştırmanın odağını oluşturan Psikoloji ve PDR lisans programları incelendiğinde, sınırlı sayıda üniversitede psikoloji bölümü lisans programlarında toplumsal cinsiyet konulu bir seçmeli ders bulunduğu; hatta PDR lisans programlarında 2018 yılına kadar böyle bir dersin yer almadığı görülmektedir. Öte yandan her iki lisans programında da psikoloji kuramları, feminist terapi, sosyal psikoloji gibi birçok konu ve ders bağlamında, cinsiyet ve cinsiyet rolleri ele alınmaktadır. Ancak bu derslerin hedefleri doğrudan toplumsal cinsiyetle ilişkili değildir. Dolayısıyla, psikolog ve psikolojik danışman adaylarının tümünün mezun olduklarında toplumsal cinsiyet eşitliğine, bu rollerin bireyin yaşamına etkisine ve meslekî yaşamlarında hizmet sunarken danışanlarının toplumsal cinsiyet rollerini nasıl göz önünde bulunduracaklarına yönelik bilgi ve beceriye sahip olduklarını söylemek güçtür.

Buradan hareketle, bu araştırmada, lisans düzeyinde öğrenim görmekte olan psikolojik danışman ve psikolog adaylarının toplumsal cinsiyet rollerine ilişkin tutumlarını ve cinsiyetçilik düzeylerini, cinsiyet ve bölüm değişkeni açısından ortaya koymak ve bu tutumların meslekî çalışmalarına nasıl etki edeceğine ilişkin görüşlerini belirlemek amaçlanmıştır. Bu çalışma ile öncelikle birer ruh sağlığı çalışanı olacak olan öğrencilerin, benzer kültürleşme sürecinin bir parçası olarak nasıl tutumlara sahip olduğu ortaya konulacaktır. Dolayısıyla, daha eşitlikçi, kültüre duyarlı ruh sağlı̆̆ı çalışanı yetiştirme konusunda bir durum tespiti yapılabilecektir. Aynı zamanda bu araştırmanın sonuçlarından yararlanarak, mesleğe başlamadan önce psikolojik danışman ve psikolog adaylarına eşitlikçi bir anlayış benimsemeleri, toplumsal cinsiyet eşitliği konusunda farkındalık ve buna uygun beceriler geliştirmeleri için gerekli eğitimler, müdahale planları düzenlenebileceği düşünülmektedir. Araştırma soruları şöyledir:

1. Psikoloji ve PDR lisans öğrencilerinin toplumsal cinsiyet rollerine ilişkin tutumları, korumacı ve düşmanca cinsiyetçilikleri, cinsiyete göre farklılaşmakta mıdır?

2. Psikoloji ve PDR lisans öğrencilerinin toplumsal cinsiyet rollerine ilişkin tutumları, korumacı ve düşmanca cinsiyetçilikleri, bölüme göre farklılaşmakta mıdır?

3. Psikoloji ve PDR lisans öğrencilerinin toplumsal cinsiyet rollerine ilişkin tutumlarının meslekî çalışmalarına etkisine ilişkin görüşleri nelerdir? 
Nicel araştırma sorularına ilişkin hipotezler aşağıda sunulmuştur:

1. Kadın öğrencilerin toplumsal cinsiyet rollerine ilişkin tutumları erkeklere göre daha eşitlikçidir ve korumacı ve düşmanca cinsiyetçilikleri daha düşüktür.

2. Psikoloji ve PDR lisans öğrencilerinin toplumsal cinsiyet rollerine ilişkin tutumları, korumacı ve düşmanca cinsiyetçilikleri bölüme göre farklılaşmaktadır.

\section{Yöntem}

\section{Araștırmanın Deseni}

$\mathrm{Bu}$ araştırma, nicel ve nitel veri toplama aşamalarını içermesi yönüyle bir karma yöntem araştırmasıdır. Elde edilecek olan nicel sonuçlara dayanarak daha geniş bilgi edinilmesi amaçlandığı için nicel veri toplama sürecinin ardından nitel veri toplama sürecinin yürütüleceği ardışı açıklayıcı desen kullanılmıştır (Creswell ve Plano Clark, 2011).

\section{Evren ve Örneklem}

$\mathrm{Bu}$ araştırmanın çalışma evreni devlet üniversitelerinin Eğitim Fakültesinde öğrenim gören PDR Bölümü öğrencileri ve Edebiyat Fakültesinde öğrenim gören Psikoloji Bölümü öğrencilerinden oluşmaktadır. Araştırmada uygun örnekleme yöntemi ile belirlenen iki devlet üniversitesinde söz konusu iki bölümde öğrenim gören dört sınıf düzeyindeki gönüllü öğrencilerden veri toplanmıştır. Araştırmaya katılmayı kabul eden, veri toplama araçlarını eksiksiz dolduran öğrencilere ilişkin bazı demografik bilgiler Tablo 1'de sunulmuştur.

Tablo 1

Nicel Verilerin Toplandığ Öğrencilerin Demografik Özelliklerine İlişkin Dağılımlar

\begin{tabular}{|c|c|c|c|c|c|c|}
\hline \multirow{3}{*}{ Cinsiyet } & & Erkek & Kadın & Belirtmeyen & & Toplam \\
\hline & $n$ & 123 & 327 & 15 & & 465 \\
\hline & $\%$ & 26.5 & 70.3 & 3.2 & & 100 \\
\hline \multirow{3}{*}{ Bölüm } & & PDR & Psikoloji & & & \\
\hline & $n$ & 192 & 273 & & & 465 \\
\hline & $\%$ & 41.3 & 58.7 & & & 100 \\
\hline \multirow{3}{*}{ Sınıf Düzeyi } & & 1 & 2 & 3 & 4 & \\
\hline & $n$ & 117 & 112 & 118 & 118 & 465 \\
\hline & $\%$ & 25.2 & 24.1 & 25.4 & 25.4 & 100 \\
\hline
\end{tabular}

Araştırmanın nitel verilerinin toplandığı örneklemi belirlemek için nicel veri toplama sürecinde katılım talebi toplanmıştır. Bireysel yüz yüze görüşmeler, araştırmanın nicel verileri toplanırken gönüllü olduğunu belirten öğrencilerle yürütülmüştür. Nicel verilerin analizinin ardından, maksimum çeşitlilik örnekleme ile veri kaynağı olan öğrencilerin özelliklerinde farklılaşmanın sağlanması için hem kadın hem erkek, farklı sınıf düzeylerinden, toplumsal cinsiyet rolleri tutum puanları, düşmanca ve korumacı cinsiyetçilik puanları en yüksek ve en düşük olan öğrenciler belirlenmiştir. Bu öğrencilerden gönüllü olduğunu belirten ve iletişim bilgilerini paylaşan 12 öğrenci ile iletişime geçilmiş, araştırmaya katılmayı kabul eden öğrencilerle görüşmeler gerçekleştirilmiştir. Sınıf düzeyi, cinsiyet ve ölçek puanlarında çeşitlilik olması amaçlanmıştır. Öğrencilerin (altı kadın, altı erkek) altısı dördüncü sınıfta, dördü birinci sınıfta, ikisi ikinci, diğer ikisi de üçüncü sınıfta öğrenim görmektedir. Öğrencilerin yaşları 18-25 arasında değişmektedir ve yaş ortalaması 20.83 'tür. Öğrencilerin sekizi, toplumsal cinsiyetle ilişkili olabilecek herhangi bir eğitime, çalıştay vb. aktivitelere katılmazken, dört öğrenci doğrudan bu nitelikte olmasa da kadın ve insan hakları kapsamında, film gösterimi, çalıştay ve kısa süreli seminerlere katıldığını belirtmiştir.

\section{Veri Toplama Araçları}

Kişisel Bilgi Formu. Araştırmacı tarafından hazırlanan uygulama formunun başında yer alan, öğrencinin cinsiyet, yaş, bölüm ve sınıf düzeyi bilgilerini belirlemeyi amaçlayan maddelerden oluşmaktadır.

Toplumsal Cinsiyet Rollerine İlişkin Tutum Ölçeği (TCRTÖ). Üniversite öğrencilerinin toplumsal cinsiyet rollerine ilişkin tutumlarının belirlenmesi için geliştirilen TCRTÖ (Zeyneloğlu ve Terzioğlu, 2011), 38 maddeden oluşan 5'li likert tipi bir ölçektir. Ölçekte, kadın cinsiyet rolü, erkek cinsiyet rolü, evlilikte cinsiyet rolü, eşitlikçi ve geleneksel cinsiyet rolü olmak üzere beş alt ölçek bulunmaktadır. Bu araştırmada genel olarak katılımcıların eşitlikçi-geleneksel tutumu ortaya koymak amaçlandığı için ölçeğin toplam puanı kullanılmıştır. Ölçekten alınabilecek en düşük puan 38, en yükssek puan 180'dir. Ölçekten alınan puanın yüksek olması, eşitlikçi 
tutuma sahip olunduğunu göstermektedir. TCRTÖ’nün Cronbach $\alpha$ değeri .92 bulunmuştur. Bu çalışma için de Cronbach $\alpha$ değeri .92 bulunmuştur.

Çelişik Duygulu Cinsiyetçilik Ölçeği (ÇDCÖ). ÇDCÖ Glick ve Fiske (1996) tarafindan geliştirilmiş ve Sakallı Uğurlu (2002) tarafından Türkçeye uyarlanmıştır. 6'lı likert tipinde 22 maddeden oluşan ölçeğin korumacı cinsiyetçilik ve düşmanca cinsiyetçilik olmak üzere 11 'er maddeden oluşan iki alt boyutu bulunmaktadır. Örnek olarak korumacı cinsiyetçilik alt boyutunda Ne kadar başarılı olursa olsun bir kadının sevgisine sahip olmadıkça bir erkek gerçek anlamda bütün bir insan olamaz; düşmanca cinsiyetçilik boyutunda ise kadınlar, erkekler üzerinde kontrolü sağlayarak güç kazanmak hevesindeler gibi maddeler yer almaktadır. Ölçekte ters puanlanması gereken madde bulunmamaktadır. Her iki alt boyut için de alınabilecek en yüksek puan 66 olup, puanın yüksek olması korumacı ve düşmanca cinsiyetçiliğin yüksek olduğu anlamına gelmektedir. Bu araştırmada hem katılımcıların sahip olduğu doğrudan ayrımcılığa işaret eden cinsiyetçiliği hem de bu cinsiyetçi yapıyı sürdüren tutumlarını ortaya koyabilmek adına iki alt boyuttan elde edilen puanlar kullanılmıştır. ÇDCÖ’nün iç tutarlık Cronbach alfa katsayısı .85 değerinde bulunmuştur. Bu araştırmada tüm ölçeğin Cronbach $\alpha$ değeri .91 bulunmuştur.

Yart Yapılandırılmış Görüşme Formu. Araştırmanın nitel veri toplama sürecinde, "bireylerin görüşlerini, deneyimlerini, duygularını ortaya çıkarma yönünden oldukça güçlü olan görüşme" (Yıldırım ve Şimşek, 2013, s. 155) yöntemi kullanılmıştır. Yarı yapılandırılmış görüşme formu oluşturulurken, ilgili literatürden yararlanarak görüşme soruları taslağı hazırlanmış; soruların araştırma sorusuna hizmet edip etmeyeceği incelenmiştir. Görüşme formlarının hazırlanmasında soruların kolay anlaşılır, açık uçlu olmasına, yönlendirici olmamasına dikkat edilmiştir (Bogdan ve Biklen, 1997). Oluşturulan taslak görüşme formu için psikoloji, psikolojik danışma ve kadın çalışmaları alanında araştırmaları olan iki uzmandan görüş alınmıştır. Görüşme formunun son hâlinde, Danışanın cinsiyeti ve sizin cinsiyetiniz psikolojik yardım sürecini nasıl etkiler?, Danışanın ve sizin benimsediğiniz toplumsal cinsiyet rollerine yönelik tutum, psikolojik yardım sürecini nasıl etkiler? gibi toplam beş soru bulunmaktadır.

\section{Veri Toplama Süreci}

Araştırmanın verileri, etik kurul izni alındıktan sonra 2018-2019 eğitim öğretim yılında toplanmıştır. Öncelikle nicel veri toplama araçları aracılığıyla veriler toplanmış, verilerin analizi sonrasında gönüllü öğrencilerden oluşan katılımcılarla yüz yüze bireysel görüşme yapılmıştır. Veri toplama sürecinde, katılımcılara bilgilendirilmiş onam formu aracılığıyla, araştırma ile ilgili detaylar aktarılmış, verilerin ve sonuçların gizliliği konusunda bilgi verilmiş, bu doğrultuda onayları alınmıştır.

Nicel veriler, ilgili bölümlerde öğrenim gören öğrencilerden ders saatleri içerisinde toplanmıştır. Uygulamalar yaklaşık 10-15 dakika sürmüş, araştırmacı tarafından gerçekleştirilmiştir. Nitel veriler ise nicel veri analizinden sonra gönüllü öğrencilerle yapılan yüz yüze bireysel görüşmeler aracılığıyla toplanmıştır. Katılımcıların onayı dahilinde tüm bireysel görüşmeler ses kaydına alınmış, söz konusu kayıtların korunması ve saklanması konusunda katılımcılar bilgilendirilmiştir.

\section{Verilerin Çözümlenmesi ve Yorumlanması}

Veri analizinde öncelikle elde edilen nicel veriler SPSS 20 Paket programında tanımlanmış, kayıp veri olup olmadığı kontrol edildikten sonra, ölçeklerde yer alan ters maddelerin puanlamaları dönüştürülmüş, veri setine son hali verilmiştir. Skewness ve Kurtosis değerleri -1, 1 arasında olduğu için verilerin normal dağılım gösterdiği görülmüştür. Tip 1 hatayı azaltmak için bağımlı değişkenler, çoklu değişken olarak ele alınmış, iki bağımsız değişkenle birlikte MANOVA yapılması hedeflenmiştir. Ancak MANOVA testi için gözlemlerin bağımsızlığı varsayımı karşılansa da Box’M ve Levene Testi sonuçları ile çoklu normallik ve varyans-kovaryans matrisinin homojenliği varsayımınının sağlanamadığı görülmüştür. Bu varsayımların sağlanması yönünde yapılması önerilen dönüşümler (Tabachnik ve Fidell, 2007) sonucunda da varsayımların karşılanmaması sebebiyle veri analizinde parametrik testlerden $t$ testi kullanılmıştır.

Yarı yapılandırılmış görüşmelerden elde edilen veriler, verilerin derinlemesine analiz edilmesini gerektiren içerik analizi ile analiz edilmiştir (Yıldırım ve Şimşek, 2013). Verilerin analizinden önce hazırlık sürecinde görüşme kayıtları yazıya dökülmüş, metin belirli aralıklarla okunmuş, anlamlı kelime ve cümle birlikleri belirlenerek literatürden de yararlanarak kodlanmıştır. Yazılı dökümler, PDR alanında uzman bir kişi tarafından, araştırmacının hazırladığı taslak kod listesinden yararlanarak yeniden kodlanmış, kodlayıcılar arasındaki tutarlılık \% 86 bulunmuştur. Bu uyuşum yüzdesinin kodlama güvenirliği için yeterli olduğu bilinmektedir (Miles ve Huberman, 1994).

\section{Nitel Veriler İçin Alınan Güvenirlik ve Geçerlik Önlemleri}

İnandırıcılığı sağlamak amacıyla veri toplama araçlarının hazırlanması sürecinde uzman görüşüne başvurulmuş, aynı zamanda veri toplama sürecinin başında pilot görüşme yapılmıştır. Veriler analiz ve rapor edilmeden önce 
katılımcı teyidi alınması amacıyla görüşmelerin yazılı dökümleri e-posta aracılığıyla katılımcılara gönderilmiştir (Shenton, 2004). Aktarılabilirliği sağlamak amacıyla raporda veriler ayrıntılı bir şekilde betimlenmiş ve ulaşılan yapının bir kanıtı olarak doğrudan alıntılar veri kaynağı çeşitliliği gözetilerek sunulmuştur (Yıldırım ve Şimşek, 2013). Tutarlılığı sağlamak amacıyla, veri kaybını önlemek için, görüşmeler katılımcıların izni doğrultusunda kayıt altına alınmıştır. Kayıtlar ve ham veriler hâlen muhafaza edilmektedir (LeCompte ve Goetz, 1982). Son olarak, araştırmanın teyit edilebilirliği için toplanan veriler ayrıntılı olarak rapor edilmiştir, sonuçlara nasıl ulaşıldığı detaylıca açıklanmıştır (Maxwell, 1996). Bununla birlikte araştırmacı, diğer araştırmacılara yol gösterici olması için araştırma raporunda araştırma sürecindeki rolünü, konumunu açıklamıştır (LeCompte ve Goetz, 1982).

\section{Araştırmacının Rolü}

Sorumlu yazar bir psikolojik danışman eğitimcisi olarak psikolojik danışman adaylarının toplumsal cinsiyet rollerine ilişkin eşitlikçi bir tutum geliştirmesine yönelik çalışmalar yürütmektedir. İkinci yazar ise psikoloji bölümünde öğretim üyesi olup psikoloji ve kadın çalışmaları alanında araştırmalar yürütmektedir. Araştırmacılar, katılımcılara toplumsal cinsiyete ilişkin herhangi bir ders vermemektedir.

\section{Etik Konular}

Araştırma için, etik kurul izni alınmıştır. Tüm katılımcılara araştırma ile ilgili bilgilendirilmiş onam formu sunulmuştur. Veriler, araştırmaya gönüllü olarak katılan öğrencilerden toplanmıştır.

\section{Bulgular}

Birinci araştırma sorusu kapsamında katılımcıların, toplumsal cinsiyet rolleri tutum puanlarının nasıl olduğu ve cinsiyete, bölüme göre farklılık gösterip göstermediğini ortaya koymak amacıyla bağımsız gruplar $t$ testi sonuçları incelenmiştir. Cinsiyetini belirtmeyen 15 katılımcının verileri analiz dışında tutulmuştur. Bağımsız gruplar $t$ testi sonuçlarına göre (Tablo 2), kadın öğrencilerin toplumsal cinsiyet rollerine ilişkin tutum puan ortalaması, erkeklerin puan ortalamalarından yüksektir. Kadın ve erkek öğrencilerin toplumsal cinsiyet rollerine ilişkin tutum puanları arasında anlamlı bir farklılık saptanmıştır $(t(448)=9.78, p<.05$, Cohen $\mathrm{d}=.41)$. Bu farklılığın etki büyüklüğünün orta olduğu görülmektedir (Cohen, 1988).

Tablo 2

Toplumsal Cinsiyet Rollerine İlişkin Tutum, Korumacı ve Düşmanca Cinsiyetçilik Puanlarının Cinsiyet Değişsenine Göre t Testi Sonuçları

\begin{tabular}{|c|c|c|c|c|c|c|}
\hline & Cinsiyet & $n$ & $\bar{X}$ & $S S$ & $t$ & $p$ \\
\hline \multirow{2}{*}{ Toplumsal Cinsiyet Rolleri } & Kadın & 327 & 174.49 & 12.89 & \multirow{2}{*}{9.78} & \multirow{2}{*}{$.00 * *$} \\
\hline & Erkek & 123 & 155.75 & 19.72 & & \\
\hline \multirow{2}{*}{ Düşmanca Cinsiyetçilik } & Kadın & 327 & 27.09 & 9.96 & \multirow{2}{*}{-13.20} & \multirow{2}{*}{$.00 * *$} \\
\hline & Erkek & 123 & 41.53 & 11.27 & & \\
\hline \multirow{2}{*}{ Korumacı Cinsiyetçilik } & Kadın & 327 & 30.84 & 11.05 & \multirow{2}{*}{-3.86} & \multirow{2}{*}{$.00 * *$} \\
\hline & Erkek & 327 & 27.09 & 9.96 & & \\
\hline
\end{tabular}

Tablo 2'de ayrıca Çelişik Duygulu Cinsiyetçilik ölçek puanlarının cinsiyet değişkenine göre bağımsız gruplar $t$ testi sonuçları sunulmuştur. Kadın ve erkek öğrencilerin düşmanca cinsiyetçilik $(t(448)=-13.20, p<.05$, Cohen $\mathrm{d}=.52)$ ve korumacı cinsiyetçilik puan ortalamaları arasında anlamlı farklılık olduğu bulunmuştur $(t(448)=-$ $3.86, p<.05$, Cohen $d=.17)$. Sonuçların etki büyüklüğünün düşmanca cinsiyetçilik için orta büyüklükte, korumacı cinsiyetçilik için ise küçük olduğu söylenebilir (Cohen, 1988).

Araştırmanın ikinci araştırma sorusu kapsamında bölüm değişkenine göre bağımsız gruplar $t$ testi sonuçları (Tablo 3), öğrencilerin toplumsal cinsiyet rollerine ilişkin tutum puan ortalamaları arasındaki farkın ise anlamlı olduğunu ortaya koymuştur $(t(463)=-3.91, p<.05$, Cohen $\mathrm{d}=.18)$. Psikoloji Bölümü öğrencilerinin puan ortalamalarının daha yüksek olduğu görülmüştür. Bu farklılığın etki büyüklüğünün küçük olduğu görülmektedir (Cohen, 1988). Çelişik Duygulu Cinsiyetçilik ölçek puanlarının bölüm değişkenine göre farklılaşıp

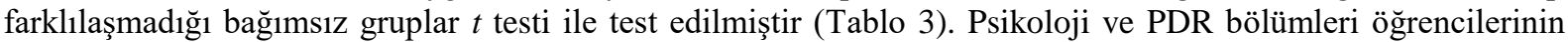
düşmanca cinsiyetçilik $(t(463)=3,08, p<.05$, Cohen $\mathrm{d}=.14$ ) ve korumacı cinsiyetçilik puan ortalamaları arasındaki farkın anlamlı olduğu görülmüştür $(t(463)=2,39, p<.05$, Cohen $\mathrm{d}=.11)$. $t$ testi sonuçları Psikoloji Bölümü öğrencilerinin düşmanca cinsiyetçilik ve korumacı cinsiyetçilik puan ortalamalarının daha düşük olduğunu ortaya koymuştur. Bu farklılıkların etki büyüklüğünün küçük olduğu görülmektedir (Cohen, 1988). 
Tablo 3

Çelişik Duygulu Cinsiyetçilik Ölçek Puanlarının Bölüm Değişkenine Göre t Testi Sonuçları

\begin{tabular}{|c|c|c|c|c|c|c|}
\hline & Bölüm & $n$ & $\bar{X}$ & SS & $t$ & $p$ \\
\hline \multirow{2}{*}{ Toplumsal Cinsiyet Rolleri } & PDR & 192 & 165.51 & 17.85 & \multirow{2}{*}{-3.91} & \multirow{2}{*}{$.00 * *$} \\
\hline & Psikoloji & 273 & 171.87 & 16.43 & & \\
\hline \multirow{2}{*}{ Düşmanca Cinsiyetçilik } & PDR & 192 & 33.20 & 11.95 & \multirow{2}{*}{3.08} & \multirow{2}{*}{$.002 * *$} \\
\hline & Psikoloji & 273 & 29.72 & 11.99 & & \\
\hline \multirow{2}{*}{ Korumacı Cinsiyetçilik } & PDR & 192 & 33.48 & 11.16 & \multirow{2}{*}{2.39} & \multirow{2}{*}{$.017^{* *}$} \\
\hline & Psikoloji & 273 & 30.98 & 11.04 & & \\
\hline
\end{tabular}

Araștırmanın üçüncü araștırma sorusu kapsamında, Psikoloji ve PDR lisans öğrencilerinin toplumsal cinsiyet rollerine ilişkin tutumlarının, meslekî çalışmalarına etkisine ilişkin görüşlerini ortaya koymayı amaçlayan verilerin içerik analizi sonuçları ise şöyledir:

Tablo 4

Nitel Veri Analizinde Ulaşılan Tema ve Alt Temalar

Tema ve Alt Temalar

$n$

Danışan/Ruh sağlığ çalışanı cinsiyet tercihi

Danışanın hemcins/karşı cins profesyoneli seçmesi 10

Danıșanın Sorun Alanı

Danışanın Kendini Açması

Ruh sağlığı çalışanının hemcins/karşı cins danışan seçmesi

Etik Sorumluluk-Eşit Davranma

6

8

Ruh Sağlığı Çalışanına İlişkin Varsayımlar

Kadınlar daha iyi bir dinleyici

Kadinlar daha iyi anlar

Kadınlar daha duygusal

Kadınlar daha şefkatli

Danışana İlişkin Varsayımlar

Kadın danışanın kendini daha kolay/zor açması 2

Erkek danışanın kendini daha kolay/zor açması 2

Kadınla erkek farklı düşünce yapılarına sahip olması

Ruh Sağlığı Çalışanının Müdahaleleri

Farkındalık kazandırma

3

Tutum değiştirmeye çalışma- tepkisel davranma

Etik davranma

Ruh Sağlı̆̆ Çalışanının İhtiyaçları

Eğitimler, seminer, söyleşilere katılma

Bireysel araştırmalar

Süpervizyon alma

Mesleki eğitim - lisans eğitimi

Gözlem yapma

Konsültasyon alma

\section{Danıșan/Ruh Sağlığı Çalıșanı Cinsiyet Tercihi}

Danışanın Hemcins/Karşı Cins Profesyoneli Seçmesi. Katılımcılar, danışanın psikolojik yardım almayı gerektiren sorun alanının ruh sağ lı̆̆ çalışanının cinsiyetine ilişkin tercihini etkileyebileceğini belirtmiştir. Aynı zamanda danışan ile ruh sağlığı çalışanının cinsiyetin benzer ya da farklı olmasının, danışanın kendini açmasında zorlaştırıcı ya da kolaylaştıııı etkileri olduğuna ilişkin görüşleri bulunmaktadır.

Katılımcıların ifadelerine göre, danışanların sorun alanı psikolojik yardım alacağı profesyonelin hemcinsi olması tercihinde belirleyici olabilmektedir. Danışanlar cinsel konuları anlatacakları zaman ruh sağlığı çalışanı olarak hemcinsini tercih edebilmektedir. Karşı cinsle ilgili yaşantıları da ruh sağ lığı çalışanının cinsiyetine dair tercihi etkileyebilmektedir. Katılımcıların ifadelerinden alıntı örnekleri aşağıda sunulmuştur: 
...cinsellikle ilgili bir sıkıntı varsa ilişkide ve kendisi de belki ona bu güne kadar öğretip öğretilen toplumsal rollerden dolayı veya cinsellik konusunda ona uygulanan baskılardan dolayı karşı cinse çok rahat aktaramayabileceğini düşünerek belki beni tercih etmeyebilir (K1, PSİ3, Erkek).

Çok çok özel durumlar olabilir mesela bir kadın anne olamayacağını öğrenmiş olabilir bu yüzden de işte herhangi bir kadın psikologun onu anlayacağı ya da anlamayacağını düşünüp ona göre bir cinsiyet seçebilir (K4, PSİ, Kadın)

Aynı zamanda, ruh sağlı̆̆ profesyonelinin cinsiyetine ilişkin tercihlerin, danışanın kendini açması ile ilişkili olduğu görülmüştür. Katılımcıların, ruh sağlığı çalışanının karşı cinsten ya da hemcinsi olmasının danışanın kendini açmasını kolaylaştırıcı ya da zorlaştırıcı olmasına ilişkin ifadeleri şöyledir:

Danışan erkekse belki kafasındaki her şeyi birden anlatabilir ama bir kadın biraz daha kapalı konuşabilir (K2, PSİ4, Erkek).

Şu bir gerçek kadınlar daha rahat hissedecektir. Erkekler biraz hani sorunlarını belki kısmen rahat hissetmeyecekleri için değiştirerek de anlatabilirler (K11, PSİ1, Kadın).

Ruh Sağlı̆̆ı Çalışanının Hemcins/Karşı Cins Danışan Seçmesi. Katılımcılar, ruh sağlığı çalışanının danışanın cinsiyetine ilişkin bir tercihi olmaması gerektiğine vurgu yapmış, etik sorumluluk gösterip, her iki cinsiyetten danışana da eşit davranması gerektiğini belirtmiştir:

Benim için aslında [danışanın cinsiyetine dair] hiçbir problem yok yani sonuçta karşımdakini bir insan olarak görüyorum o cinsiyet benim için odaya geldiği zaman cinsiyet önemli değil (K9, PDR4, Erkek).

Psikolojik danışman herkese eşit mesafede yaklaşabilmeli ve bunu hissettirebilmeli (K10, PSİ2, Erkek).

\section{Ruh Sağlığı Çalışanına İlişkin Varsayımlar}

Katılımcıların daha ziyade danışanların kadın ruh sağlığı çalışanlarına ilişkin varsayımlar olduğundan söz ettikleri görülmüştür. $\mathrm{Bu}$ varsayımlar, kadınların daha iyi bir dinleyici oldukları, danışanları daha iyi anladıkları, daha şefkatli ve duygusal oldukları şeklindedir:

Biraz toplumdaki bakış açısı da olabilir. Kadınlar daha iyi dinler daha iyi anlar gibi. Kadınları daha çok seçeceklerini düşünüyorum nedense (K3, PDR4, Kadın).

...kadın olarak bizim daha şefkatli daha anaç olduğumuzu düşünerek insanlar bence daha çok kadın psikolog tercih ediyorlar (K4, PSİ, Kadın).

...kadın evlidir, evliliğini anlatıyordur, kadına, biraz daha duygusallaştığı için sorularımı ona göre seçebilirim (K2, PSI4, Erkek).

\section{Danışana İlişkin Varsayımlar}

Katılımcılar, danışanların da cinsiyetine bağlı olarak düşünce tarzındaki ve kültürel değerlerde kadın danışan kendini daha kolay/zor açar, kadınla erkek farklı düşünce yapılarına sahiptir, erkekler daha kolay/zor anlatır şeklinde farklılıklar olabileceğini belirtmiştir:

Psikolojik danışmanların iki cinsiyetin de genel düşüncelerini bilmeleri gerektiğini düşünüyorum. Yani hem biyolojik anlamında hem düşünce anlamında neye doğru yönelimler bunu bilerek o terapi sürecinde ilerlemeleri gerektiğini düşünüyorum. Çünkü cinsiyet farklılıkları düşünceler üzerinde de etkili oluyor... Kadınların olaylara vereceği tepkiler ve duygusal değişimleri erkeklere göre daha farklı olabiliyor (K11, PSİ1, Kadın).

...erkek danışan kendini daha zor açıyormuş, kadınlar kendini daha iyi ifade edebiliyor (K3, PDR4, Kadın).

\section{Ruh Sağlığı Çalışanının Müdahaleleri}

Katılımcılar, danışanlarının benimsedikleri toplumsal cinsiyet rolleri ile kendi rolleri arasında farklılıklar olduğunda danışana farkındalık kazandırma, tepkisel davranma, etik davranma olarak başlıklandırılan müdahalelerden söz etmiştir:

Amacım orda onun böyle bir rolü üstlendiğini farkına varmasını sağlamak olur onun farkında olsun başka seçeneklerin de olduğunun farkında olsun hiçbir role bürünmesine gerek olmadığını farkına vardırmaya çalışırım. Tüm seçenekleri önüne sunmaya çalışırım bilinç düzeyine aktarmaya çalışırım ondan sonra ona kalır gerisi öyle düşünüyorum (K7, PDR,2 Kadın).

Benim buradaki tutumum eşitlikçi olacaktır ama hanı bunu bir dayatma şeklinde değil de sanırım bununla ilgili konuşabiliriz bu işte sohbette ben eşitlikçi düşünüyorumdur kendisi geleneksel düşünüyordur ama bunu konuşarak tutumu o an konuşuruz konuşma süreci tutumu etkiler diye düşünüyorum (K10, PSİ1, Erkek)

Muhtemelen o konularda çok objektif olamıyorum diye düşünüyorum. Eğer danışanım çok fazla gelenekçiyse o söylediği gelenekler benim kafamdaki profil de yanlışsa muhtemelen düşüncelerini değiştirmeye çalışırım diye düşünüyorum. Hani çünkü bana göre o bir dayatmadır ve bunu sadece kendisi düşünmüyordur 
başkalarına dayatıyordur. Ben onun düşüncelerini değiştirebilirsem o da başkalarının düşüncelerini değiştirebilir (K4, PSİ4, Kadın).

Kendi fikirlerimde empoze etme şekli değil de eğer bu [geleneksel] tutumların ona zarar verdiğini görüyorsam açıkçası onları değiştirmeye çalışırım. Mesela sosyalleşmek isteyen birisi bir danışan fakat kadın danışan olsun erkeklerle sosyalleşmek istemiyor ya da sosyalleşemiyor, açıkçası toplum herhangi inancından dolayı diyelim bu ona zarar veriyorsa eğer sosyalleșmesini engelliyorsa bunun üzerine çalışmak isterim açıkçası değiştirmek isterim kafasındaki düşünceleri ya biraz yanlış inançlar gibi aslında (K9, PDR4, Erkek).

Önemli olan karșıdaki insan bir problemle geliyor ve ona en iyi șekilde nasıl yardımcı olabilirim bu hangi kimliğe sahipsem sahip olayım benim düşünmem gereken tek şey bu ona yardımcı olabilmek bu amaçla yaklaşırım isterse bana çok zıt olsun sadece bu şeyi hani nasıl desem üslubumu belki biraz daha değiştirebilirim onunla konuşurken onun dışında yaklaşımım farklı olmayacaktır (K11, PSİ1, Kadın).

\section{Ruh Sağlığı Çalışanının İhtiyaçları}

Tüm katılımcılar, toplumsal cinsiyet rollerinin psikolojik danışma sürecine olası etkilerine dair farkındalık kazanma, bilgi edinme, becerilerini geliştirme konusundaki ihtiyaçlarını belirtmişlerdir. Bu ihtiyacı eğitimlere, seminerlere katılma, bireysel olarak araştırmalar yapma, lisans eğitiminde çeşitli dersler alma, bireyleri gözlemleme ve süpervizyon alma ile giderebileceklerini düşündükleri görülmektedir:

Çeşitli eğitimler varsa çok bilgim dahilinde değil tabiî ki ama hepsini almak isterim öncelikle özellikle karș1 cins hakkında onun toplumdaki rolü ve ona toplum tarafindan yüklenen herhangi bir kimlik ya da statï şeylerini daha ayrıntılı öğrenmek ve bilimsel olarak öğrenmek isterim yani tabi ben de toplumun bir bireyi olarak gözlemleyebiliyorum ama bunun birde bilimsel boyutu var yani o boyutunu öğrenmek isterim bunun yardımcı olacağını düşünüyorum (K8,PSİ1, Kadın).

Şu an bazı okumalar kendimce yaptım ama ben bile farkında olmadan belki de yanlış yaptığım şeyler olabiliyor. Kendimle çelişen davranışlar sergiliyor olabilirim bilmediğimden kaynaklı ya bunun açıkçası daha iyi bir şey görmek isterim. Bunun için birkaç kere toplumsal cinsiyet eşitliği üzerine konferans seminer tarzı şeylere katılmıştım, ama tabi daha bir kapsamlı bir şey öğrenmek isterim. Özellikle psikolojik danışmaya yönelik olursa daha çok (K9, PDR4, Erkek).

Bence asıl önemli olan süpervizyon aldıkları kişinin bu olaylara nasıl baktığıyla alakalı. Süpervizyon veren kişi cinsiyetçi ise ve terapist adayı da bu süreçten etkilenebilir olumsuz bir şekilde ve bunu da kendi danışanlarına yansıtabilir belki ve danışan seçimini de buna göre yapabilir belki bu biraz usta çırak ilişkisi ile yürüdüğü için terapistlik yani birazcık da üst merciinin nasıl baktığı bu olaylara nasıl yaklaştığı da önemli. İlk aşamada süpervizyon veren kişilerin yüksek lisans programlarındaki akademisyenlerin bu olaylara nasıl baktığı ve onlara belki ilk aşamada farkındalık kazandırılmalı bundan sonra... Kadın çalışmaları, toplumsal cinsiyet ana bilim dalı, psikoloji bölümünde ders açabilirler. Seçmeli olarak ya da zorunlu da olabilir. Bu şekilde bir farkındalık kazandırılabilir bu konuda (K1, PSİ4, Erkek).

\section{Sonuç ve Tartışma}

$\mathrm{Bu}$ araştırmada PDR ve Psikoloji Bölümü öğrencilerinin toplumsal cinsiyet ve çelişik duygulu cinsiyetçilik tutumlarının ortaya konması, bu tutumların cinsiyete ve bölüme göre farklılaşıp farklılaşmadığının belirlenmesi, bununla birlikte öğrencilerin bu tutumlarının sunacakları psikolojik yardım hizmetine olası etkilerine ilişkin görüşlerinin incelenmesi amaçlanmıştır. Araştırmanın bulgularından ilki kadın ve erkek öğrencilerin toplumsal cinsiyet rollerine ilişkin tutum puanları arasında anlamlı bir farklılık olduğunu ortaya koymaktadır. Araştırmanın birinci hipotezinde öne sürüldüğü gibi, kadın öğrencilerin toplumsal cinsiyet rollerine ilişkin tutumları daha eşitlikçidir. Aynı zamanda kadın ve erkek öğrencilerin düşmanca cinsiyetçilik ve korumacı cinsiyetçilik puan ortalamaları arasında anlamlı farklılık olduğu görülmüştür. Literatürde cinsiyetin toplumsal cinsiyet algısında belirleyici olduğunu (Esen ve diğ., 2017), erkeklerin daha geleneksel tutuma sahip olduğunu (Pesen ve diğ., 2016; Sis Çelik ve diğ., 2013; Vefikuluçay ve diğ., 2007), erkek öğrencilerin düşmanca cinsiyetçilik puanlarının kadın öğrencilerden yüksek olduğunu ve kadın öğrencilerin korumacı cinsiyetçiliklerinin daha yüksek düzeyde olduğunu (Alptekin, 2014; Taşdemir ve Sakall1-Uğurlu, 2010) ortaya koyan araştırma sonuçlarının (Vefikuluçay ve diğ., 2007) bu bulgularla paralellik gösterdiği söylenebilir. Başka bir araştırmada da erkek okul psikolojik danışmanlarının cinsiyetçilik düzeyi de kadın okul psikolojik danışmanlarının cinsiyetçilik düzeyinden daha yüksek bulunmuştur (Dinçer, 2016). Bu araştırmada erkeklerin düşmanca cinsiyetçilik tutum puanlarının yüksekliği, üniversite öğrencisi ve ruh sağlığı çalışanı adayı olarak düşündürücü bir bulgudur. Korumacı cinsiyetçilik tutum puanları kadınlarda daha düşük çıksa da her iki cinsiyetten de öğrencilerin cinsiyet eşitsizliğini pekiştiren algılara sahip olduklarını ortaya koymaktadır.

Araştırmanın ikinci hipotezine ilişkin bulgu ise, Psikoloji Bölümü öğrencilerinin toplumsal cinsiyet rollerine ilişkin tutum puan ortalamalarının daha yüksek olduğudur. Dolayısıyla Psikoloji Bölümü öğrencilerinin toplumsal cinsiyet rollerine ilişkin daha eşitlikçi tutuma sahip oldukları söylenebilir. Aynı zamanda Psikoloji Bölümü öğrencilerinin korumacı ve düşmanca cinsiyetçilik puan ortalamalarının daha düşük olması, iki 
bulgunun birbirini desteklediğini göstermektedir. Bu konuda oldukça sınırlı sayıda araştırma olsa da Dinçer'in (2016) yaptığı araştırmada İstanbul'daki okul psikolojik danışmanlarının cinsiyetçilik düzeylerinin ortalamanın üstünde olduğunu tespit etmiştir. İki bölümün derslerinin temelde benzer olduğu düşünüldüğünde lisans eğitim programlarının da bu konuda belirleyici görünmediği söylenebilir. Bu noktada hem öğrenci hem de öğretim üyelerinin profilinin farklılaştığı söylenebilir. Eğitim fakültesi, öğretmen yetiştirmeyi temel alan bir fakülte olmasından dolayı, öğrencilerin bu fakülteyi ve buradaki bölümleri seçme nedenlerine bakıldığında iş garantisi, çalışma koşullarının rahat olması (Aksu, Demir, Daloğlu, Yıldırım ve Kiraz, 2010; Eret-Orhan ve Ok, 2014) gibi sebepler ortaya konmaktadır. Bu durum bu fakülteyi isteyerek seçen öğrenciler dışında, görece daha düşük sosyoekonomik düzeyden (Aksu ve diğ., 2010; Saban, 2003), anne baba eğitim düzeyi düşük (Eret-Orhon ve Ok, 2014) öğrencileri kapsadığını düşündürebilir. Ancak bölümler arası farklılığı neyin yarattığının daha detaylı incelenmesine, toplumsal cinsiyet rollerine ilişkin algıları etkileyen öğrencilerin yaşamlarının çoğunu geçirdikleri yer, toplumsal cinsiyet rollerinin oluşumu, anne-babanın eğitim durumu, anne-baba tutumu gibi pek çok faktörün etkisini ortaya koyacak, bulguların tümünü birlikte değerlendirme firsatı sunacak araştırmalara ihtiyaç olduğu düşünülmektedir.

Araştırmanın nitel bulguları ise öğrencilerin, danışan ve psikolojik danışman/terapist cinsiyet eşleşmeleri, danışanın toplumsal cinsiyet rollerine ilişkin tutumunun psikolojik yardım sürecinde nasıl etkileri olabileceği hakkındaki görüşlerini sunmaktadır. Benzer araştırmalardaki sonuçlarla (Haskan Avcı, Tuna, Büyükçolpan, Güngör ve Yörükoğlu, 2019; Landes, Burton, King ve Sullivan, 2013; Waller ve Katzman, 1998) paralel olarak katılımcılar, danışanların ruh sağlığı hizmeti alacağı kişinin cinsiyetine dair tercihlerinin, yardım alacakları sorun alanına göre değişebileceğini belirtmiştir. Danışanların paylaşımları cinsel konularla ilişkili olduğunda hemcinsi olan profesyonellerle çalışma eğiliminde olabileceğini belirtmişlerdir. Haskan Avcı ve diğerleri (2019) araştırmasında da cinsel konular söz konusu olduğunda bireylerin psikolojik danışman tercihlerinin hemcinsleri olduğu görülmektedir. Kadınların kişisel konularda kadın psikolojik danışman seçimlerinin daha fazla olduğu (Fuller, 1964; Yanico ve Hardin, 1985), meslekî ve eğitsel konularda, erkek psikolojik danışmanların daha fazla tercih edildiği de bilinmektedir.

Aynı zamanda öğrencilerin, danışanların kendini daha rahat açabileceği cinsiyetle çalışmayı tercih ettiklerini düşündükleri görülmektedir. Araştırmalar, danışanların kadın psikolojik danışmanlara kendilerini daha rahat açtıkları ve rahat hissettiklerini (Landes ve diğ.,2013), aynı cinsiyetten olan danışan terapist eşleşmelerinin danışanın cinsel konularda kendini açmada kolaylaştırıcı olduğunu (Zane ve Ku, 2014) ortaya koymaktadır. Aynı cinsiyetten hasta ve terapistlerin dünya ve sorunlar üzerinde benzer bakış açıları olabileceği, hemcinslerle çalışıldığında daha iyi ilişki kurulduğu, terapiyi tamamlama ihtimalinin daha yüksek olduğu bilinmektedir (Wintersteen, Mensinger ve Diamond, 2005). Ancak cinsiyet eşleşmeleri ve psikolojik yardım sürecine etkisi ile ilgili daha fazla araştırmaya ihtiyaç bulunmaktadır. Danışanların tercihlerini daha iyi kavramak, sürecin başında en uygun terapist-danışan eşleşmesine yardımcı olabilecektir (Cole, Petronzi, Singley ve Baglieri, 2019).

Katılımcıların kadın ruh sağlığı çalışanlarına ilişkin "Kadınlar daha iyi bir dinleyicidir.”, "Kadınlar daha iyi anlar." şeklindeki algıları dikkat çekmektedir. Haskan Avcı ve diğerlerinin (2019) araştırma bulguları da, katılımcıların kadınların paylaşımıı, anlaşılır ve daha empatik olması gibi algılarının olduğunu göstermektedir. $\mathrm{Bu}$ bulgular, katılımciların benzer toplumsal cinsiyet algılarına sahip olduklarını ya da bu tutumları sıklıkla gözlemlemiş olabileceklerini düşündürmektedir. Öte yandan katılımcıların bu inançlarının nasıl oluştuğu, hangi deneyimlerin etkisiyle bu algıya sahip oldukları bilgisini edinmenin gerekli olduğu düşünülmektedir.

Cinsiyet ve cinsiyet rollerinin etkisini terapötik bir şekilde ele almak, ruh sağlı̆̆ çalışanlarının meslekî ve etik sorumluluğudur. Birer ruh sağlığı çalışanı olacak olan katılımcıların kendilerinden farklı ya da geleneksel cinsiyet rollerine sahip danışanlarla çalışmaya ilişkin etik hususlara değinmeleri umut vericidir. Ancak danışanlarının tutum ve değerlerin yanlış/zarar verici olduğunu temel alarak değişiklik yaratma çabasına girmeye ilişkin ifadeleri dikkat edilmesi gereken bir noktadır. Amerikan Psikolojik Danışmanlık Derneği (ACA, 2014) ve Türk Psikologlar Derneği [TPD] (2004) Etik Yönetmeliği toplumsal cinsiyet rollerine ilişkin konuların psikolojik yardım sürecine olan etkisinin ve kendi kişisel, kültürel ve sosyal özelliklerinin sunduğu hizmete getirdiği kısıtlamaların farkında olmanın önemine vurgu yapmaktadır. Dolayısıyla psikolojik yardım sürecini yürütürken önceliklerinin, danışana saygı ve danışanın iyiliğini korumak olduğunu akıllarında tutmalarının önemini vurgulamak gerekmektedir.

Bulgular, katılımcıların toplumsal cinsiyet rollerinin psikolojik danışma sürecine olası etkilerine dair farkındalık kazanma, bilgi edinme, becerilerini geliştirme konusundaki ihtiyaçlarını belirttiğini ortaya koymaktadır. Bu ihtiyaçları için eğitimlere, seminerlere katılmayı, bireysel olarak araştırmalar yapmayı, lisans eğitiminde çeşitli dersler aracılığıyla, bireyleri gözlemleme yoluyla ve süpervizyonla kazanabileceklerini belirtmişlerdir. Bu bulguyu katılımcıların çok kültürlü yeterliklerini geliştirmeye dair ihtiyaçlarının bir parçası olarak düşünmek mümkündür. Bir araştırmada, sağlıklı cinsiyet rollerini benimseyen psikolojik danışmanların çok kültürlü yeterliklerinin daha yüksek olduğu ve çok kültürlülükle ilgili daha fazla eğitimlere katıldıkları görülmüştür (Chao ve Nath, 2011). Dolayısıyla daha cinsiyetçi tutum benimseyen öğrencilerin farkındalıklarının 
arttırılmasına ihtiyaç olduğu düşünülmektedir. Farkındalık kazanmaları noktasında Wester ve Vogel (2002) ruh sağlığı çalışanlarının kendilerine Kadın ve erkeğe neyin uygun olduğuna ilişkin farklı inanışlarım var mı? Danışanların geleneksel rol normlarına uymamasını, uyanlara kıyasla daha fazla mı patolojik algılıyorum? Danışanlara tanı koyarken/ problemini kavramsallaştırırken ve müdahale ederken farklı cinsiyet rol beklentilerini mi kullanıyorum? sorularını sormasını önermektedir.

Dolunay-Cug, Toplu-Demirtaş ve Murray’in (2017) ruh sağlığı çalışanlarının aile içi şiddet ve cinsel şiddetle ilgili deneyimlerini ve tutumlarını ele aldığı araştırmada sonuçlar, ruh sağlığı çalışanlarının farkındalık kazanmaları ve kendilerini daha yeterli hissedebilmeleri için lisans veya lisansüstü düzeyde doğrudan konuyla ilgili bir ders/eğitim almalarının gereğini ortaya koymaktadır. Doğrudan konuyla ilgili bir ders ya da eğitim almanın gereği doğrultusunda, toplumsal cinsiyet rollerinin psikolojik danışmaya etkileri konusunda farkındalık, bilgi ve beceri kazanmaları için eğitimler düzenlenmesi, her iki lisans programında da toplumsal cinsiyet rolleri ile ilgili seçmeli ya da zorunlu dersler konulması gerektiği düşünülmektedir. 2018 yılından itibaren PDR lisans programlarında seçmeli ders statüsünde yürütülmeye başlanan Toplumsal Cinsiyet Eşitliği dersinin bu ihtiyaca yönelik olarak yürütülmesi önem kazanmaktadır ve etkililiğinin incelenmesi gerektiği düşünülmektedir.

Aynı zamanda uygulama dersleri kapsamında öğrencilerin her iki cinsiyetle de etkileşime geçerek gözlemleme firsatı sağlanması; topluma hizmet uygulamaları gibi sosyal sorumluluk içeren derslerde, toplumsal cinsiyetle ilişkili projelerde yer almalarının teşvik edilmesi; temel psikolojik danışma/görüşme becerileri gibi derslerin toplumsal cinsiyet rollerinin etkisini ele almalarını destekleyecek şekilde yürütülmesi; uygulamalara yönelik yürütülen süpervizyon sürecinde de süpervizörlerin toplumsal cinsiyete duyarlı olarak öğrencilere model olması önerilmektedir.

Ayrıca ruh sağlığı çalışanlarının toplumsal cinsiyet rollerine ilişkin tutumlarının, sundukları hizmetlere etkisinin tartışılması gereği (Koçyiğit, Alkan ve Yılmaz, 2017) açık olsa da Türkiye'deki araştırmalar oldukça sınırlıdır. Bu konuların ruh sağlığı alanı için henüz keşfedilmeyi bekleyen bir araştırma alanı olduğu söylenebilir. Özellikle öğrencilerin daha eşitlikçi tutum geliştirmeleri için deneysel ve yarı deneysel araştırmalar yürütülmesi önerilmektedir. Öte yandan bu araştırma, Türkiye'deki bu örneklem ile yapılan ilk çalışma olsa da araştırmanın yalnızca bir üniversitedeki öğrencilerle yürütülmesi sebebiyle toplumsal cinsiyet ve cinsiyetçi tutumların kültürel farklılıklarını ortaya koyabilmek için sınırlıdır. Çeşitli bölgelerdeki üniversitelerden toplanacak verilerle benzer araştırmalar daha genellenebilir sonuçlar sunacaktır. Ayrıca sosyoekonomik düzey, anne baba eğitim durumu gibi farklı demografik bilgilerin alınması, ortaya çıkabilecek farklılaşmaları açıklamak için daha detaylı veri sağlayabilir.

Etik Kurul İzin Bilgisi: Bu araştırma, Ege Üniversitesi Sosyal ve Beşeri Bilimler Bilimsel Araştırma ve Yayın Etiği Kurulunun 31/01/2019 tarihli 70221511-302.08.01.-E. 21822 sayll Kararl ile alınan izinle yürütülmüş̧ür. 


\section{Kaynakça/References}

Acar Erdol, T., Özen, F. ve Toraman, Ç. (2019). Türkiye'deki eğitim fakültesi öğrencilerinin toplumsal cinsiyet eşitliğine yönelik görüşleri. Kirşehir Eğitim Fakültesi Dergisi, 20(2), 793-844. doi:10.29299/kefad.2019.20.02.009

Akın, A. ve Demirel, S. (2003). Toplumsal cinsiyet kavramı ve sağlığa etkileri. CÜ Tlp Fakültesi Dergisi, 25(4), 73-82.

Aksu, M., Demir, C. E., Daloğlu, A., Yildirim, S., \& Kiraz, E. (2010). Who are the future teachers in Turkey? Characteristics of entering student teachers. International Journal of Educational Development, 30(1), 91101. doi: 10.1016/j.ijedudev.2009.06.005

Alptekin, D. (2014). Çelişik duygularda toplumsal cinsiyet ayrımcıllı̆ı sorgusu: Üniversite gençliğinin cinsiyet algısına dair bir araştırma. Selçuk Üniversitesi Sosyal Bilimler Enstitüsü Dergisi, (32), 203-211.

American Counseling Association [ACA]. (2014). The ACA Code of Ethics. Retrieved from https://www.counseling.org/resources/aca-code-of-ethics.pdf

Ayan, S. (2014). Cinsiyetçilik: Çelişik duygulu cinsiyetçilik. Cumhuriyet Tip Dergisi, 36(2), 147-156.

Ayhan, H. (2015). Cinsel tacize iliş̧kin tutumları yordayan faktörler: Çelişik duygulu cinsiyetçilik, kontrol odă̆ı ve empati. (Yayımlanmamış yüksek lisans tezi). Haliç Üniversitesi, İstanbul.

Başçı, B. ve Giray, S. (2016). Üniversite öğrencilerinin toplumsal cinsiyet rollerine ilişkin tutumlarının çok değişkenli istatistiksel tekniklerle analizi. Journal of Life Economics, 3(4), 117-142. doi:10.15637/jlecon.160

Berger, J. M., Levant, R., McMillan, K. K., Kelleher, W., \& Sellers, A. (2005). Impact of gender role conflict, traditional masculinity ideology, alexithymia, and age on men's attitudes toward psychological help seeking. Psychology of Men \& Masculinity, 6(1), 73-78. doi:10.1037/1524-9220.6.1.73

Bilge, F. ve Ulukaya, S. (2011, Ekim). Toplumsal cinsiyet eşitliği/eşitsizliği çerçevesinde Türkiye'de psikolojik danışmanların eğitimi. Sözel Bildiri, XI. Ulusal Psikolojik Danışma ve Rehberlik Kongresi, Ege Üniversitesi, İzmir.

Bogdan, R., \& Biklen, S. K. (1997). Qualitative research for education. Boston, MA: Allyn \& Bacon.

Brown, S. (2017). Is counselling women's work? Therapy Today, 28(2), 8-11. Retrieved from http://0search.ebscohost.com.library.metu.edu.tr/login.aspx?direct=true $\& d b=a 9 h \& A N=122252688 \&$ site $=$ ehostlive

Büyükşahin Çevik, G. (2014). Kültür merkezli psikolojik danışma: Kuramsal bir inceleme. Ege Eğitim Dergisi,15(2), 577-596. doi:10.12984/eed.20938

Chao, R. C. L., \& Nath, S. R. (2011). The role of ethnic identity, gender roles, and multicultural training in college counselors' multicultural counseling competence: A mediation model. Journal of College Counseling, 14(1), 50-64. doi:10.1002/j.2161-1882.2011.tb00063.x

Chapleau, K. M., Oswald, D. L., \& Russell, B. L. (2007). How ambivalent sexism toward women and men support rape myth acceptance. Sex Roles, 57(1-2), 131-136. doi:10.1007/s11199-007-9196-2

Cohen, J. (1988). Statistical power analysis for the behavioral sciences (2nd ed.). Hillsdale, NJ: Erlbaum.

Cole, B. P., Petronzi, G. J., Singley, D. B., \& Baglieri, M. (2019). Predictors of men's psychotherapy preferences. Counselling and Psychotherapy Research, 19(1), 45-56. doi:10.1002/capr.12201

Corey, G. (2008). Psikolojik danışma kuram ve uygulamaları. (T. Ergene, çev.) Ankara: Mentis Yayıncılık.

Cormier, S., \& Hackney, H. (2014). Psikolojik danışma: Stratejiler ve müdahaleler (2. baskı). (S. Doğan ve B. Yaka çev. ed.). Ankara: Pegem Akademi.

Creswell, J. W., \& Plano Clark, V. L. (2011). Designing and conducting mixed research methods. Thousand Oaks: Sage.

Deniz, İ. (1995). Bir grup depresif hastanın bazı ailesel ve psikososyal özellikleri üzerine bir araştırma. (Yayımlanmamış yüksek lisans tezi). Karadeniz Teknik Üniversitesi, Trabzon.

DeVoe, D. (1990). Feminist and nonsexist counseling: Implications for the male counselor. Journal of Counseling \& Development, 69(1), 33-36. doi:10.1002/j.1556-6676.1990.tb01451.x 
Dinçer, F. (2016). Rehber öğretmenlerin kişilerarası ilişkilerinin yükleme karmaşılı̆̆ğ ve cinsiyetçilik bağlamında incelenmesi: İstanbul ili örneği. (Yayımlanmamış yüksek lisans tezi). Marmara Üniversitesi, İstanbul.

Dolunay-Cug, F., Toplu-Demirtaş, E., \& Murray, C. E. (2017). Turkish mental health professionals' experiences and perspectives toward family and sexual violence. Journal of Family Violence, 32(7), 731-740. doi:10.1007/s10896-017-9926-3

Englar-Carlson, M. (2006). Masculine norms and the therapy process. In Englar-Carlson, M. E., \& Stevens, M. A. (Eds.), In the room with men: A casebook of therapeutic change, (pp. 13-47). Washington DC: American Psychological Association. doi:10.1037/11411-002

Ercan, N. (2009). The predictors of attitudes toward physical wife abuse: Ambivalent sexism, system justification and religious orientation. (Unpublished master's thesis). Middle East Technical University, Ankara.

Eret-Orhan, E. ve Ok, A. (2014). Öğretmenlik programlarını kimler tercih ediyor? Adayların giriş özellikleri ve öğretmenliğe yönelik tutumları. Hacettepe Üniversitesi Ĕ̆itim Fakültesi Dergisi, 29(4), 75-92.

Erkan, S., Özbay, Y., Çankaya, Z. C. ve Terzi, Ş. (2012). Üniversite öğrencilerinin yaşadıkları problemler ve psikolojik yardım arama gönüllükleri. Eğitim ve Bilim, 37(164), 94-107.

Esen, E., Siyez, D., Soylu, Y. ve Demirgürz, G. (2017). Üniversite öğrencilerinde toplumsal cinsiyet algısının toplumsal cinsiyet rolü ve cinsiyet değişkenlerine göre incelenmesi. E-Uluslararası Eğitim Araştırmaları Dergisi, 8(1). 46-63. doi:10.19160/5000197327

Evans, M. P. (2013). Men in counseling: A content analysis of the Journal of counseling \& Development and Counselor Education and Supervision 1981-2011. Journal of Counseling \& Development, 91(4), 467-474. doi:10.1002/j.1556-6676.2013.00119.x

Fuller, F. F. (1964). Preferences for male and female counselors. Personnel \& Guidance Journal, 42(5), 463467.

Glick, P., \& Fiske, S. T. (1996). The Ambivalent Sexism Inventory: Differentiating hostile and benevolent sexism. Journal of Personality and Social Psychology, 70(3), 491-512. doi:10.1111/1471-6402.t01-100068 .

Glick, P., Sakalli-Uğurlu, N., Ferreira, M. C., \& Souza, M. A. D. (2002). Ambivalent sexism and attitudes toward wife abuse in Turkey and Brazil. Psychology of Women Quarterly, 26(4), 292-297. doi:10.1111/1471-6402.t01-1-00068

Good, G. E., Dell, D. M., \& Mintz, L. B. (1989). Male role and gender role conflict: Relations to help seeking in men. Journal of Counseling Psychology, 36(3), 295-300. doi:10.1037/0022-0167.36.3.295

Güney, N., Karg1, E. ve Çorbac1-Oruç, A. (2004). Üniversite öğrencilerinin eşcinsellik konusundaki görüşlerinin incelenmesi. Turkish Journal of HIV/AIDS, 7, 131-137.

Hackney, H. \& Cormier, L. S. (2008). Psikolojik danışma ilke ve teknikleri: Psikolojik yardım süreci el kitabı. (T. Ergene ve S. Aydemir-Sevim, çev.). Ankara: Mentis Yayıncılık.

Haskan Avc1, Ö., Tuna, B., Büyükçolpan, H., Güngör, A. ve Yörükoğlu, M. (2019). Üniversite öğrencilerinin psikolojik danışman tercihlerinin incelenmesi. Türk Psikolojik Danışma ve Rehberlik Dergisi, 9(52), 209239.

Heppner, P. P., Wampold, B. E., \& Kivlighan, D. M. (2008). Research Designs in Counseling (3rd ed.) Belmont, CA: Thomson Higher Education.

Kalkan, M. ve Odacı, H. (2005). Cinsiyet ve cinsiyet rolünün psikolojik yardım almaya ilişkin tutumlarla ilişkisi. Türk Psikolojik Danışma ve Rehberlik Dergisi, 3(23), 57-64.

Koçyiğit Özyiğit, M., Alkan, E. ve Yılmaz, M. (2017). Toplumsal cinsiyet rolleri duyarlılığı grup rehberliği programının psikolojik danışman adaylarının toplumsal cinsiyet rollerine ilişkin tutumlarına etkisi. Uluslararası Sosyal Araştırmalar Dergisi, 10(49), 315-326.

Lambert, M. J., Bergin, A. E., \& Garfield, S. L. (2004). Introduction and historical overview. In M. J. Lambert (Eds.). Handbook of psychotherapy and behavior change (5th ed.) (pp. 3-15). New York: Wiley.

Landes, S. J., Burton, J. R., King, K. M., \& Sullivan, B. F. (2013). Women's preference of therapist based on sex of therapist and presenting problem: An analog study. Counselling Psychology Quarterly, 26(3-4), 330342. doi:10.1080/09515070.2013.819795 
LeCompte, M. D., \& Goetz, J. P. (1982). Problems of reliability and validity in ethnographic research. Review of educational research, 52(1), 31-60. doi:10.3102/00346543052001031

Levant, R. F., Wimer, D. J., Williams, C. M., Smalley, K., \& Noronha, D. (2009). The relationships between masculinity variables, health risk behaviors and attitudes toward seeking psychological help. International Journal of Men's Health, 8, 3-21. doi:10.3149/jmh.0801.3

Maxwell, J. A. (1996). Qualitative research design. (1th ed.). Thousand Oaks CA: Sage.

McCarthy, J., \& Holliday, E. L. (2004). Help-seeking and counseling within a traditional male gender role: An examination from a multicultural perspective. Journal of Counseling \& Development, 82, 25-32. doi:10.1002/j.1556-6678.2004.tb00282.x

Michel, R. E., Hall, S. B., Hays, D. G., \& Runyan, H. I. (2013). A mixed methods study of male recruitment in the counseling profession. Journal of Counseling \& Development, 91(4), 475-482. doi:10.1002/j.15566676.2013.00120.x

Miles, M. B., \& Huberman, A. M. (1994). Qualitative data analysis: An expanded sourcebook. Thousand Oaks: Sage.

Nam, S. K., Chu, H. J., Lee, M. K., Lee, J. H., Kim, N., \& Lee, S. M. (2010). A meta-analysis of gender differences in attitudes toward seeking professional psychological help. Journal of American College Health, 59(2), 110-116. doi:10.1080/07448481.2010.483714

O'Neil, J. M. (2013). Gender role conflict research 30 years later: An evidence-based diagnostic schema to assess boys and men in counseling. Journal of Counseling \& Development, 91(4), 490-498. doi:10.1002/j.15566676.2013.00122.x

Oswald, D. L., Franzoi, S. L., \& Frost, K. A. (2012). Experiencing sexism and young women's body esteem. Journal of social and clinical psychology, 31(10), 1112-1137. doi:10.1521/jscp.2012.31.10.1112

Pederson, E. L., \& Vogel, D. L. (2007). Male gender role conflict and willingness to seek counseling: Testing a mediation model on college-aged men. Journal of Counseling Psychology, 54(4), 373-384. doi:10.1037/0022-0167.54.4.373

Pesen, A., Kara, İ., Kale, M. ve Abbak, B. S. (2016). Üniversite öğrencilerinin toplumsal cinsiyet alg1S1 ile çatışma ve şiddete ilişkin farkındalık düzeylerinin incelenmesi. OPUS Uluslararası Toplum Araştırmaları Dergisi, 6(11), 325-340.

Quinn, P., \& Chan, S. (2009). Secondary school students' preferences for location, format of counselling and gender of counselor: A replication study based in Northern Ireland. Counselling and Psychotherapy Research, 9(3), 204-209. doi:10.1080/14733140903031119

Saban, A. (2003). Sınıf öğretmeni adaylarının demografik özellikleri ve mesleki eğilimleri. Ĕ̆itim Araştırmaları, 10, 91-101.

Sakall1-Uğurlu, N. (2002). Çelişik duygulu cinsiyetçilik ölçeği: Geçerlik ve güvenirlik çalışması. Türk Psikoloji Dergisi, 17(49), 47-58.

Sakallı-Uğurlu, N., \& Glick, P. (2003). Ambivalent sexism and attitudes toward women who engage in premarital sex in Turkey. Journal of Sex Research, 40(3), 296-302. doi:10.1080/00224490309552194

Sakall1-Uğurlu, N., Salman, S., \& Turgut, S. (2010). Predictors of Turkish women's and men's attitudes toward sexual harassment: Ambivalent sexism, and ambivalence toward men. Sex Roles, 63(11-12), 871-881. doi: doi.org/10.1007/s11199-010-9847-6

Salman, S. (2007). The predictors of attitudes toward sexual harassment: Locus of control, ambivalent sexism, and gender differences. (Unpublished master's thesis). Middle East Technical University, Ankara.

Scher, M., \& Good, G. E. (1990). Gender and counseling in the twenty-first century: What does the future hold? Journal of Counseling \& Development, 68(4), 388-391. doi:10.1002/j.1556-6676.1990.tb02516.x

Seçgin, F. ve Tural, A. (2011). Sınıf öğretmenliği bölümü öğretmen adaylarının toplumsal cinsiyet rollerine ilişkin tutumları. e-Journal of New World Sciences Academy, 6(4), 2446-2458.

Shenton, A. K. (2004). Strategies for ensuring trustworthiness in qualitative research projects. Education for information, 22(2), 63-75. doi:10.3233/EFI-2004-22201

Sis Çelik, A., Pasinlioğlu, T., Tan, G. ve Koyuncu, H. (2013). Üniversite öğrencilerinin cinsiyet eşitliği tutumlarının belirlenmesi. Florence Nightingale Hemşirelik Dergisi, 21(3), 181-186. 
Tabachnick, B. G., \& Fidell, L. S. (2007). Using multivariate statistics (5th ed.). Boston, MA: Pearson.

Tarhan, S., Çetin Gündüz, H., \&Ekşioğlu, S. (2017). Ambivalent sexism, gender and attitudes towards violence against women in marriage. Journal of Human Sciences, 14(2), 1894-1908. doi:10.14687/jhs.v14i2.4474

Taşdemir, N., \& Sakall1-Uğurlu, N. (2010). The relationships between ambivalent sexism and religiosity among Turkish university students. Sex Roles, 62(7-8), 420-426. doi:10.1007/s11199-009-9693-6

Topkaya, N. ve Meydan, B. (2013). Üniversite öğrencilerinin problem yaşadıkları alanlar, yardım kaynakları ve psikolojik yardım alma niyetleri. Trakya Üniversitesi Ĕ̈itim Fakültesi Dergisi, 3(1), 25-37.

Türk Psikologlar Derneği [TPD]. (2004). Türk psikologlar derneği etik yönetmeliği. http://www.psikolog.org.tr/turkey-code-tr.pdf adresinden elde edildi.

Umucu, E. ve Voltan Acar, N. (2011). Grupla psikolojik danışma sürecinde direnç öğesi olan kültürel etmenlere psikolojik danışmanın müdahalesi. Ege Eğitim Dergisi, 12(1), 99-113.

Ünal, F., Tarhan, S. ve Çürükvelioğlu Köksal E. (2017). Toplumsal cinsiyet algısını yordamada cinsiyet, sınıf, bölüm ve toplumsal cinsiyet oluşumunun rolü. Bartın Üniversitesi Ĕgitim Fakültesi Dergisi, 6(1), 227-236. doi:10.14686/buefad.287496

Vefikuluçay, D., Zeyneloğlu, S., Eroğlu, K. ve Taşkın, L. (2007). Kafkas Üniversitesi son sınıf öğrencilerinin toplumsal cinsiyet rollerine ilişkin bakış açıları. Hemşirelik Yüksekokulu Dergisi, 26-38.

Waller, G., \& Katzman, M. A. (1998). Female or male therapists for women with eating disorders? A pilot study of experts' opinions. International Journal of Eating Disorders, 23(2), 117-123. doi:10.1002/(SICI)1098108X(199803)23:2<117::AID-EAT1>3.0.CO;2-N

Wester, S. R., \& Vogel, D. L. (2002). Working with the masculine mystique: Male gender role conflict, counseling self-efficacy, and the training of male psychologists. Professional Psychology: Research and Practice, 33(4), 370-376. doi:10.1037/0735-7028.33.4.370

Wintersteen, M. B., Mensinger, J. L., \& Diamond, G. S. (2005). Do gender and racial differences between patient and therapist affect therapeutic alliance and treatment retention in adolescents? Professional Psychology: Research and Practice, 36(4), 400-408. doi:10.1037/0735-7028.36.4.400

Yalçın, Z. S. (2006). Effects of ambivalent sexism, locus of control, empathy, and belief in a just world on attitudes toward rape victims. (Unpublished master's thesis). Middle East Technical University, Ankara.

Yanico, B. J., \& Hardin, S. I. (1985). Relation of type of problem and expectations of counselor knowledge and understanding to students' gender preferences for counselors. Journal of Counseling Psychology, 32(2), 197-205

Yazıcı, F. ve Budak, F. (2017). Eğitim fakültesi öğrencilerinin kimlik farklılıklarına karşı tutumlarının farklı değişkenler açısından incelenmesi. International Online Journal of Educational Sciences, 9(3), 879-896. doi:10.15345/iojes.2017.03.020

Yıldırım, A. ve Şimşek, H. (2013). Sosyal bilimlerde nitel araştırma yöntemleri. (9. baskı). Ankara: Seçkin Yayıncılık.

Yücel, B. (2009). Estetik bir kaygıdan hastalığa uzanan yol: Yeme bozuklukları. İlk Söz, 22(4), 39-45.

Zane, N., \& Ku, H. (2014). Effects of ethnic match, gender match, acculturation, cultural identity, and face concern on self-disclosure in counseling for Asian Americans. Asian American Journal of Psychology, 5(1), 66-74. doi:10.1037/a0036078

Zeyneloğlu, S. ve Terzioğlu, F. (2011). Toplumsal Cinsiyet Rolleri Tutum Ölçeği'nin geliştirilmesi ve psikometrik özellikleri. Hacettepe Üniversitesi Eğitim Fakültesi Dergisi, 40, 409-420. 